4th National Seminar on Guidance and Counseling (SNBK 2019) and Workshop on

Pedagogical Theory and Practice (WTPP 2019)

SHEs: Conference Series 2 (2) (2019) $142-147$

\title{
Penerapan Alat Peraga Papan Berpaku untuk Meningkatkan Pemahaman Konsep Persegi dan Persegi Panjang
}

\author{
Siti Yunia', Yusuf Suryana², Winarti Dwi Febriani ${ }^{3}$ \\ 1,3 Universitas Perjuangan Tasikmalaya, ${ }^{2}$ Universitas Pendidikan Indonesia \\ sitiyunia0410@gmail.com
}

\section{Article History}

accepted 2/11/2019

approved 23/11/2019

published 31/12/2019

\begin{abstract}
The purpose of this study was to improve the ability to understand square and rectangular concepts in mathematics learning using nailed board teaching aids for third grade students at SDN 3 Sukamanah. The method used in this study is the Classroom Action Research (CAR) method. The results showed that the planning of learning and the process of implementing mathematics learning on each cycle increased. Learning planning in the first cycle reached a percentage of $79.46 \%$. In the second cycle reached a percentage of $89.28 \%$ and in the third cycle reached a percentage of $96.43 \%$. The results of observations of the ability to understand the concept of square and rectangular in the first cycle reached a percentage of $58 \%$. In cycle II it was $86.54 \%$ and in cycle III it reached a percentage of $98 \%$. The learning process was not optimal before the use of the nailed board teaching aids, this can be seen from the test results of the ability to understand the concept of square and rectangular pre-action which reached $25 \%$. Data obtained in cycle I reached $44 \%$, in cycle II it reached $69 \%$ and in cycle III it reached $88 \%$. Based on the improvement data from each cycle, learning mathematics using nail board props can improve the ability to understand square and rectangular concepts in class III SDN 3 Sukamanah, Cipedes District, Tasikmalaya City, Academic Year 2018/2019.
\end{abstract}

Keywords: Understanding, Square and rectangular concepts, Classroom Action Research, Nailing Board Props.

\begin{abstract}
Abstrak
Tujuan penelitian ini adalah untuk meningkatkan kemampuan pemahaman konsep persegi dan persegi panjang dalam pembelajaran matematika menggunakan alat peraga papan berpaku pada siswa kelas III SDN 3 Sukamanah. Metode yang digunakan dalam penelitian ini yaitu metode Penelitian Tindakan Kelas (PTK). Hasil penelitian menunjukkan bahwa perencanaan pembelajaran dan proses pelaksanaan pembelajaran matematika pada setiap siklus mengalami peningkatan. Perencanaan pembelajaran pada siklus I mencapai persentase sebesar $79,46 \%$. Pada siklus II mencapai persentase sebesar $89,28 \%$ dan pada siklus III mencapai perentase sebesar 96,43\%. Hasil pengamatan kemampuan pemahaman konsep persegi dan persegi panjang pada siklus I mencapai persentase sebesar 58\%. Pada siklus II sebesar $86,54 \%$ dan pada siklus III mencapai persentase $98 \%$. Proses belajar belum optimal sebelum digunakannya alat peraga papan berpaku, hal ini dapat dilihat dari nilai hasil tes kemampuan pemahaman konsep persegi dan persegi panjang pra tindakan yang mencapai 25\%. Data yang diperoleh pada siklus I mencapai 44\%, pada siklus II mencapai 69\% dan pada siklus III mencapai $88 \%$. Berdasarkan data peningkatan dari setiap siklus, pembelajaran matematika dengan menggunakan alat peraga papan berpaku dapat meningkatkan kemampuan pemahaman konsep persegi dan persegi panjang di kelas III SDN 3 Sukamanah Kecamatan Cipedes Kota Tasikmalaya Tahun Ajaran 2018/2019.
\end{abstract}

Kata kunci: Pemahaman, Konsep persegi dan persegi panjang, Penelitian Tindakan Kelas, Alat Peraga Papan Berpaku.

Social, Humanities, and Education Studies (SHEs): Conference Series https://jurnal.uns.ac.id/shes

p-ISSN 2620-9284

e-ISSN 2620-9292

This work is licensed under a Creative Commons Attribution-ShareAlike 4.0 International License. 


\section{PENDAHULUAN}

Silabus Kurikulum Tingkat Satuan Pendidikan (KTSP) kelas III mata pelajaran matematika khususnya materi bangun datar, siswa dikatakan paham terhadap konsep bangun datar, apabila siswa dapat mencapai indikator yaitu:(1) Mengelompokkan macam-macam bangun datar menurut bentuknya; (2) Mengurutkan bangun-bangun datar menurut ukurannya; (3) Menentukan pola serangkaian bangun datar dan (4) Menggambar macam-macam bentuk bangun datar. Berdasarkan empat indikator tersebut diharapkan siswa mampu meningkatkan kemampuan pemahaman konsep matematis dalam pembelajaran bangun datar.

Berdasarkan hasil pembelajaran matematika di kelas III SDN 3 Sukamanah pada kompetensi dasar bangun datar khusunya pada materi persegi dan persegi panjang masih belum mencapai pada Kriteria Ketentuan Minimal yang ditetapkan yaitu 68. Dari 16 siswa kelas III yang mendapat nilai di atas 68 hanya 5 orang siswa atau $31,25 \%$. Sedangkan 11 siswa atau 68,75\% belum mencapai KKM. Data diperoleh dari hasil wawancara guru kelas III dengan melihat daftar nilai siswa. Salah satunya dalam pembelajaran bangun datar, kendala yang dihadapi siswa dalam pembelajaran bangun datar adalah siswa kurang paham mengenai unsur dan sifat-sifat bangun datar sederhana karena dalam penjelasannya belum menggunakan media yang sesuai untuk menunjang pembelajaran bangun datar. Serta adanya faktor lain yang membuat pembelajaran kurang bermakna dan kurangnya pemahaman siswa yaitu karena kemampuan dan karakteristik setiap siswa berbeda-beda, siswa kurang terlibat aktif dalam proses pembelajaran, dan juga kurangnya penggunaan media pembelajaran yang sesuai dengan materi pembelajaran bangun datar. Sehingga peneliti akan menggunakan salah satu alternatif media pembelajaran yang diharapkan dapat meningkatkan hasil belajar siswa serta sesuai dengan materi pembelajaran bangun datar yaitu dengan penerapan alat peraga papan berpaku.

Berdasarkan hasil penelitian terdahulu, Dolhasair (2017) menunjukkan bahwa Penggunaan alat peraga papan berpaku dalam pembelajaran matematika pada materi bangun datar, mampu meningkatkan aktivitas belajar dan kemampuan pemahaman siswa dibandingkan tanpa penggunaan alat peraga dalam pembelajaran. Sejalan dengan pendapat di atas, Sopiyah \& Rohita (2014) dari hasil penelitiannya menyimpulkan bahwa Penerapan alat peraga papan berpaku mampu membuat anak memahami pembelajaran, membuat anak lebih senang dan termotivasi dalam memperhatikan penjelasan guru.

Tujuan penelitian ini adalah (1) Mendeskripsikan perencanaan pembelajaran dengan menggunakan alat peraga papan berpaku sehingga dapat meningkatkan kemampuan pemahaman konsep persegi dan persegi panjang pada siswa kelas III SDN 3 Sukamanah; (2) Mendeskripsikan proses pelaksanaan pembelajaran pada materi persegi dan persegi panjang dengan menggunakan alat peraga papan berpaku di kelas III SDN 3 Sukamanah; (3) Mendeskripsikan keberhasilan penerapan alat peraga papan berpaku sehingga mampu meningkatkan kemampuan pemahaman konsep persegi dan persegi panjang pada siswa kelas III SDN 3 Sukamanah.

\section{METODE}

Metode penelitian yang digunakan adalah penelitian tindakan kelas. Penelitian ini dilaksanakan di SDN 3 Sukamanah tahun ajaran 2018/2019 selama tujuh bulan. Mulai dari Februari 2019 sampai dengan Agustus 2019. Subjek Penelitian ini adalah siswa kelas III SDN 3 Sukamanah yang berjumlah 16 siswa. Terdiri atas 7 siswa lakilaki dan 9 siswa perempuan. 
Data yang diambil pada penelitian ini yaitu data kuantitatif dan data kualitatif. Data kuantitatif berupa nilai hasil tes kemampuan pemahaman konsep persegi dan persegi panjang pada siswa, dan data kualitatif berupa dokumentasi dan hasil observasi pada aktivitas siswa dan aktivitas guru dengan menggunakan alat peraga papan berpaku pada proses pembelajaran. Teknik pengumpulan data yang digunakan pada penelitian ini yaitu teknik tes dan teknik non tes berupa soal evaluasi dan lembar observasi. Data yang diperoleh dalam penelitian ini kemudian dianalisis melalui kegiatan reduksi data, display data, kesimpulan dan verifikasi.

\section{HASIL DAN PEMBAHASAN}

Penelitian dilaksanakan di kelas III SDN 3 Sukamanah Kecamatan Cipedes Kota Tasikmalaya, pada mata pelajaran matematika semester II dengan penerapan alat peraga papan berpaku untuk meningkatkan kemampuan pemahaman konsep persegi dan persegi panjang. Dalam penelitian diperoleh data berdasarkan instrumen pengamatan RPP, pengamatan kinerja peneliti, pengamatan kemampuan pemahaman konsep, dan pengamatan hasil tes kemampuan pemahaman konsep.

Kompetensi Dasar (KD) yang digunakan pada penelitian ini yaitu 5.1 Menghitung keliling, luas persegi dan persegi panjang. Materi yang diajarkan yaitu menyebutkan sifat-sifat persegi dan persegi panjang, menyebutkan contoh benda sekitar yang termasuk dalam bangun datar, menghitung keliling persegi dan persegi panjang serta menghitung luas persegi dan persegi panjang. Pelaksanaan penelitian dilaksanakan dalam tiga siklus. Hasil penelitian setiap siklus terdapat perencanaan, pelaksanaan, observasi dan refleksi.

1. Perencanaan

Peneliti membuat RPP sesuai dengan silabus mata pelajaran matematika dengan kompetensi dasar: 5.1 Menghitung keliling, luas persegi dan persegi panjang. RPP yang dibuat dinilai menggunakan lembar penilaian RPP disesuaikan dengan langkahlangkah pembelajaran dengan menggunakan alat peraga papan berpaku. Lembar penilaian RPP ini dinilai oleh guru mitra sebagai observer. Penilaian RPP dengan menggunakan alat peraga papan berpaku pada proses pembelajaran dapat dilihat pada tabel 1. Berikut:

Tabel 1. Perbandingan Nilai RPP Siklus I,II, dan III

\begin{tabular}{lll}
\hline Siklus & Persentase & Kategori \\
\hline I & $79,46 \%$ & Cukup \\
II & $89,28 \%$ & Baik \\
III & $96,43 \%$ & Sangat Baik \\
\hline
\end{tabular}

Berdasarkan data pada tabel 1, dapat diketahui adanya peningkatan yang diperoleh data dari siklus I, siklus II sampai dengan siklus III. Dari hasil tersebut menunjukkan hasil penilain RPP yang diperoleh pada siklus I memperoleh nilai sebesar $79,46 \%$ dengan kategori "Cukup", pada siklus II memperoleh nilai sebesar 89,28 \% dengan kategori "Baik" sedangkan pada siklus III memperoleh nilai sebesar 96,43\% dengan kategori "Sangat Baik". Antara siklus I dan siklus II telah terjadi peningkatan sebesar $9,82 \%$ dan antara siklus II dan III telah terjadi peningkatan sebesar $7,15 \%$. Oleh karena itu, RPP yang dibuat pada ketiga siklus tersebut sudah baik dan layak untuk diimplementasikan dalam sebuah pembelajaran.

2. Pelaksanaan 
Pada tahap pelaksanaan peneliti mengimplementasikan RPP yang telah dibuat sebelumnya. Tahap ini terdiri dari kegiatan pendahuluan, kegiatan inti, dan kegiatan akhir. Pelaksanaan pembelajaran dinilai oleh guru mitra sebagai observer menggunakan lembar observasi kinerja guru dan pengamatan kemampuan pemahaman konsep matemtika siswa. Peningkatan nilai kinerja guru dan pengamatan kemampuan pemahaman konsep matematika siswa dapat dilihat pada tabel 2. berikut:

Tabel 2. Perbandingan kinerja guru dan pengamatan kemampuan pemahaman konsep matematika siswa siklus I, II dan III

\begin{tabular}{ccccc}
\hline \multirow{2}{*}{ Siklus } & \multicolumn{2}{c}{ Kinerja Guru } & \multicolumn{2}{c}{$\begin{array}{c}\text { Pengamatan kemampuan pemahaman } \\
\text { konsep matematika siswa }\end{array}$} \\
& Skor & Kriteria & Skor & Kriteria \\
\hline I & $78,75 \%$ & Cukup & $58 \%$ & Kurang \\
II & $88,75 \%$ & Baik & $86,54 \%$ & Baik \\
II & $96,25 \%$ & Sangat Baik & $98 \%$ & Sangat Baik \\
\hline
\end{tabular}

Data pada tabel 2, menunjukkan peningkatan kemampuan pemahaman konsep matematika siswa dan kinerja guru dari siklus I, siklus II sampai dengan siklus III. Pada siklus I nilai kinerja guru adalah $78,75 \%$ dengan kategori "Cukup", pada siklus II nilainya sebesar $88,75 \%$ dengan kategori "Baik" sedangkan pada siklus III mengalami peningkatan sebesar 96,25\% dengan kategori "Sangat Baik". Berdasarkan hasil yang diperoleh tersebut, artinya telah terjadi peningkatan persentase kinerja guru yaitu dari siklus I ke siklus II sebesar $10 \%$ dan dari siklus II ke siklus III sebesar $7,5 \%$. Adapun hasil yang diperoleh berdasarkan pengamatan kemampuan pemahaman konsep matematika siswa, pada siklus I adalah 58\% dengan kategori "Kurang", pada siklus II sebesar $86,54 \%$ dengan kategori "Baik" sedangkan pada siklus III meningkat dengan nilai $98 \%$ dengan kategori "Sangat baik". Artinya telah terjadi peningkatan dari siklus I ke siklus II sebesar $28,54 \%$ dan sari siklus II ke siklus III sebesar 11,46\%. Hal ini menunjukkan bahwa instrumen pengamatan tersebut pada setiap siklus sudah berhasil.

3. Hasil Tes Kemampuan Pemahaman Konsep Persegi dan Persegi Panjang Hasil tes kemampuan pemahaman konsep persegi dan persegi panjang diperoleh berdasarkan evaluasi hasil belajar yag diberikan setelah akhir pembelajaran. Peningkatan evaluasi hasil belajar siswa dapat dilihat pada tabel 3 berikut:

Tabel 3. Perbandingan Hasil Tes Kemampuan Pemahaman Konsep Persegi dan Persegi Panjang pada siklus I,II dan III

\begin{tabular}{cccc}
\hline Hasil Tes Evaluasi & \multirow{2}{*}{ Nilai Rata-rata } & \multicolumn{2}{c}{ Persentase } \\
Siswa & & Tuntas & Belum Tuntas \\
\hline Siklus I & 60,62 & $44 \%$ & $56 \%$ \\
Siklus II & 77,5 & $69 \%$ & $31 \%$ \\
Siklus III & 86,87 & $88 \%$ & $12 \%$ \\
\hline
\end{tabular}

Berdasarkan data pada tabel 3 , dapat diketahui adanya peningkatan nilai rata-rata hasil tes evaluasi siswa dan persentase ketuntasan belajar klasikal siswa dari pelaksanaan siklus I sampai siklus III. Hasil yang diperoleh menunjukkan bahwa pada saat siklus I nilai yang diperoleh adalah 60,62 dengan persentase ketuntasan belajar klasikal yaitu $44 \%$. Pada siklus II, nilai rata-rata yang diperoleh yaitu 77,5 dengan 
persentase $69 \%$ dan pada siklus III mengalami peningkatan lebih tinggi yaitu dengan nilai rata-rata 86,87 dengan persentase sebesar $88 \%$.

Proses pembelajaran dengan penerapan alat peraga papan berpaku membuat siswa lebih aktif dalam proses pembelajaran, secara keseluruhan siswa mulai tertarik menyimak penjelasan dari guru, siswa mampu merespon pertanyaan dari guru, siswa percaya diri dalam mengemukakan pendapat, dan sebagian besar siswa sudah mampu menghubungkan antara teori dan praktek sehingga peragaan papan berpaku berjalan maksimal disambut seluruh siswa. Hal tersebut dapat dilihat dari setiap indikator meningkat dan sudah terpenuhi dengan baik dari siklus I ke siklus II sampai siklus III sehingga hasil belajar siswa dapat meningkat.

Hasil tes kemampuan pemahaman konsep siswa pada proses pembelajaran dengan penerapan alat peraga papan berpaku, dapat diperoleh dari hasil penilaian secara individu dengan mengerjakan soal-soal tes evaluasi tentang materi persegi dan persegi panjang setelah proses pembelajaran berlangsung. Hasil belajar siswa dari tiga siklus ini menunjukkan hasil tes kemampuan pemahaman konsep yang beragam dari masing-masing siswa. Melihat dari data hasil penelitian yang dilakukan pada pembelajaran siklus I, II dan III, siswa mengalami peningkatan hasil tes kemampuan pemahaman konsep setelah melewati proses pembelajaran dengan penerapan alat peraga papan berpaku pada materi persegi dan persegi panjang di kelas III SDN 3 Sukamanah. Hal ini dibandingkan dengan hasil tes kemampuan awal yang dilakukan oleh peneliti sebelum diterapkannya media pembelajaran. Siswa mengalami perubahan suasana dalam pembelajarannya di kelas yang dapat berpengaruh terhadap hasil belajar yang akan diperolehnya. Berdasarkan apa yang telah diungkapkan oleh Sudjana, Nana (2016:111) "Proses belajar adalah penunjang hasil belajar yang ingin dicapai siswa."

Jadi berdasarkan uaraian hasil penelitian terhadap hasil tes kemampuan pemahaman konsep siswa, dapat dilihat bahwa dengan penerapan alat peraga papan berpaku pada materi persegi dan persegi panjang dapat meningkatkan kemampuan pemahaman konsep siswa. Hasil data dari setiap siklus siswa dapat dikatakan berhasil, karena sudah terlihat adanya peningkatan dan sudah dapat mencapai kriteria keberhasilan yang telah ditetapkan, yaitu secara individu siswa sudah mengalami peningkatan kemampuan pemahaman konsep karena tidak kurang dari 75\% (14 orang siswa) dari jumlah 16 orang siswa kelas III SDN 3 Sukamanah dan sudah dapat mencapai nilai di atas KKM 68. Sehingga dari Penelitian Tindakan Kelas ini, sudah dapat terlihat peningkatan kemampuan pemahaman konsep siswa.

Data peningkatan hasil tes kemampuan pemahaman konsep siswa dengan penerapan alat peraga papan berpaku pada pembelajaran siklus I, II dan III, dapat dilihat pada gambar 4 . berikut ini:

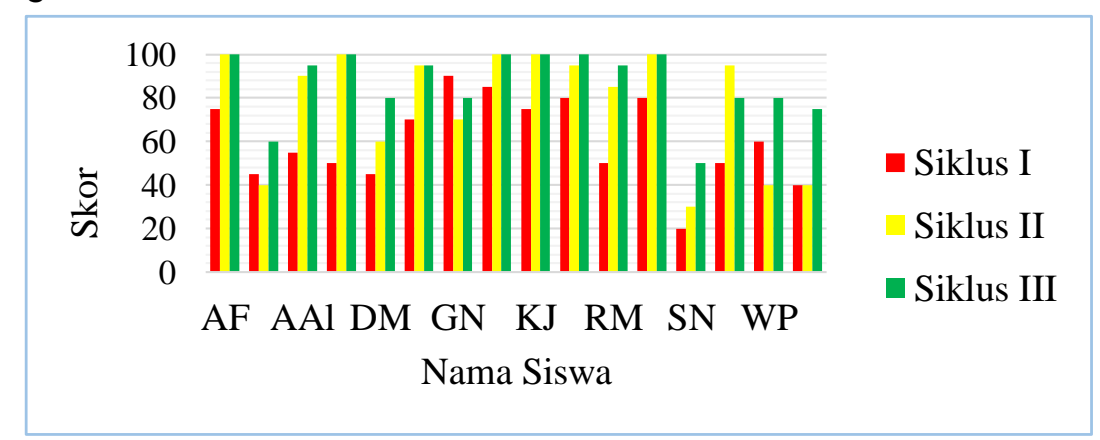

Gambar 1. Grafik Peningkatan Hasil Tes Kemampuan Pemahaman Konsep Persegi dan Persegi panjang 
Berdasarkan gambar grafik 4. dapat disimpulkan bahwa hasil tes kemampuan pemahaman siswa pada konsep persegi dan persegi panjang mengalami peningkatan setelah diterapkannya alat peraga papan berpaku di Kelas III SDN 3 Sukamanah.

\section{SIMPULAN}

1. Pada siklus pertama peneliti memberikan soal tes kemampuan awal sebelum diterapkannya alat peraga papan berpaku, kemudian diberikan tindakan sesuai dengan langkah dalam rencana pelaksanaan pembelajaran yang diamati oleh observer (guru kelas), pada setiap akhir pembelajaran siswa diberikan soal tes evaluasi, dan peneliti merefleksi seluruh kegitan pelaksanaan penelitian untuk perbaikan pada siklus ke II dan ke III. Hasil penelitian menunjukkan bahwa peneliti membuat perencanaan pembelajaran yang sesuai, ditandai dengan adanya peningkatan pemenuhan aspek-aspek dari setiap siklus.

2. Pelaksanaan pembelajaran matematika pada materi persegi dan persegi panjang dengan menggunakan alat peraga papan berpaku di kelas III SDN 3 Sukamanah dapat berjalan dengan baik, sesuai dengan perencanaan pembelajaran yang telah ditentukan. Pelaksanaan pembelajaran dengan menggunakan alat peraga papan berpaku dapat memotivasi siswa dalam proses pembelajaran menjadi lebih aktif sehingga kemampuan pemahaman konsep persegi dan persegi panjang siswa meningkat.

3. siklus I ketuntasan belajar siswa mencapai persentase sebesar $44 \%$ ( 7 orang siswa) dan yang belum tuntas KKM 56\% (9 orang siswa) dengan rata-rata yang diperoleh 60,625. Siklus II mencapai persentase 69\% (11 orang siswa) tuntas belajar, dan $31 \%$ (5 orang siswa) belum tuntas KKM dengan rata-rata kelas yang diperoleh 77,5 . Siklus III mencapai persentase $88 \%$ (14 orang siswa ) tuntas belajar, dan hanya $12 \%$ (2 orang siswa) yang belum tuntas KKM dengan rata-rata kelas yang diperoleh 86,875 .

\section{DAFTAR PUSTAKA}

Dolhasair, G. (2017). Penggunaan Media Geoboard (Papan Bepaku) untuk Meningkatkan Pemahaman Konsep Bangun Datar pada Siswa Kelas II Sekolah Dasar. Jurnal Didaktika Dwija Indria, 5 (3), 1-8.

Herawati, O.D.P. (2010). Pengaruh Pembelajaran Problem Posing Terhadap Kemampuan Pemahaman Konsep Matematika Siswa Kelas XI IPA SMA Negeri 6 Palembang. Jurnal Pendidikan Matematika, 4 (1), 71-80.

Hernawan, A.H., Zaman, B., dan Riyana, C. (2007). Media Pembelajaran SD. Bandung: UPI PRESS.

Mayasari, N. (2017). Pemanfaatan Media Pembelajaran Geoboard dalam Pembelajaran Matematika. Jurnal Pengabdian Kepada Masyarakat, 1 (1), 6065.

Sopiyah, \& Rohita. (2014). Meningkatkan Kemampuan Kognitif Anak dalam Mengenal Bentuk Geometri Melalui Bermain Papan Berpaku dengan Kartu Geometri Kelompok Usia 3-4 Tahun di PPT Bougenville. Jurnal Pendidikan Matematika, 3 (3), 1-6. 